\title{
SENSITIVITY TO NITRATE AND NITRITE IN POND-BREEDING AMPHIBIANS FROM THE PACIFIC NORTHWEST, USA
}

\author{
Adolfo Marco, $* \dagger$ Consuelo Quilchano, $\neq$ and Andrew R. Blaustein $§$ \\ $†$ Departamento de Biología Animal, Universidad de Salamanca, Salamanca 37071, Spain \\ \$Instituto de Recursos Naturales y Agrobiología, Consejo Superior de Investigaciones Científicas, Salamanca 37071, Spain \\ $\S$ Department of Zoology, Oregon State University, Corvallis, Oregon 97331, USA
}

(Received 27 July 1998; Accepted 11 March 1999)

\begin{abstract}
In static experiments, we studied the effects of nitrate and nitrite solutions on newly hatched larvae of five species of amphibians, namely Rana pretiosa, Rana aurora, Bufo boreas, Hyla regilla, and Ambystoma gracile. When nitrate or nitrite ions were added to the water, some larvae of some species reduced feeding activity, swam less vigorously, showed disequilibrium and paralysis, suffered abnormalities and edemas, and eventually died. The observed effects increased with both concentration and time, and there were significant differences in sensitivity among species. Ambrystoma gracile displayed the highest acute effect in water with nitrate and nitrite. The three ranid species had acute effects in water with nitrite. In chronic exposures, $R$. pretiosa was the most sensitive species to nitrates and nitrites. All species showed $15-\mathrm{d}$ LC50s lower than $2 \mathrm{mg} \mathrm{N}-\mathrm{NO}_{2}-/ \mathrm{L}$. For both $\mathrm{N}$ ions, $B$. boreas was the least sensitive amphibian. All species showed a high mortality at the U.S. Environmental Protection Agencyrecommended limits of nitrite for warm-water fishes $\left(5 \mathrm{mg} \mathrm{N}-\mathrm{NO}_{2}-\mathrm{L}\right)$ and a significant larval mortality at the recommended limits of nitrite concentration for drinking water $\left(1 \mathrm{mg} \mathrm{N}-\mathrm{NO}_{2}-\mathrm{L}\right)$. The recommended levels of nitrate for warm-water fishes $(90 \mathrm{mg} \mathrm{N}-$ $\left.\mathrm{NO}_{3}-/ \mathrm{L}\right)$ were highly toxic for $R$. pretiosa and A. gracile larvae.
\end{abstract}

Keywords-Amphibian decline Fertilizers Interspecific comparison Nitrate Nitrite

\section{INTRODUCTION}

Species losses are occurring at unprecedented rates, primarily through habitat destruction and alteration [1-3]. As part of this biodiversity crisis, many amphibian species are exhibiting population declines and range reductions (cf., recent reviews in [47]). Although habitat destruction is a major cause for amphibian population losses, it does not seem to explain the decline of populations of certain amphibian species in relatively undisturbed areas, where suitable habitat seems to be available. It is possible, however, that what seems to be suitable habitat for amphibians may be habitat that has been significantly altered. For example, chemicals used for various purposes may permeate lakes, ponds, and streams, making them unsuitable for amphibians.

Water pollution and poor water quality are of global concern. Many chemical products used in agriculture and industry pollute aquatic habitats, causing potential severe damage to ecosystems [8,9]. Specifically, the increase in concentrations of nitrate in surface water on agricultural land due to diffuse sources may be hazardous to many wildlife species (cf., $[10,11])$. Nitrate-related compounds may have negative effects on humans and fishes (methemoglobinemia, carcinogenesis $[9,12,13])$, and ammonium nitrate fertilizer has an acute effect on adult frogs [14]. Aquatic larval stages of some amphibians are also susceptible to the negative effects of nitrate and nitrite [15-19]. The early stages of many amphibians are restricted to the aquatic environment, being susceptible to dermal absorption of toxic compounds and to ingestion of contaminated materials in the water [20,21]. Recent data suggest that nitrogen-based fertilizers may be contributing to the decline of some amphibian populations in agricultural lands [14,22,23].

* To whom correspondence may be addressed. The current address of A. Marco is Estación Biológica de Doñana, Apartado 1056, Sevilla 41080, Spain.
Recent reports indicate that the Oregon spotted frog, Rana pretiosa Baird and Girard 1853, has disappeared from most of its known historical range in the last four decades [24,25]. These lowland areas have an intense agricultural use, and we hypothesized that agricultural chemicals such as nitrogenous fertilizers could have contributed to the near extirpation of $R$. pretiosa from the Willamette Valley [26,27] and lowland valleys of the state of Washington, USA [24]. Red-legged frog, $R$. aurora Baird and Girard 1852, seems to be lees common than it once was in the heavily agricultural Willamette Valley [28,29]. Western toad, Bufo boreas Baird and Girard 1852, is not common in valleys of Oregon and Washington, USA [28,29]. Other amphibians such as Pacific treefrog, Hyla regilla Baird and Girard 1852, and northwestern salamander, Ambystoma gracile Baird 1857, are still present in these valleys, and a lower sensitivity to these pollutants could be one reason why their populations appear to persist in areas where ranid frog populations have declined.

To test the hypothesis that amphibians are sensitive to environmental levels of nitrate and nitrite and that there are interspecific differences in sensitivity to both ions, we studied the dose-effect relationship of these ions on $R$. pretiosa, $R$. aurora, $B$. boreas, $H$. regilla, and $A$. gracile larvae using static laboratory experiments. We established median lethal concentrations (LC50s) at 4, 7, and $15 \mathrm{~d}$ for both $\mathrm{N}$ ions for each species.

\section{MATERIALS AND METHODS}

\section{Study species}

We collected $R$. aurora and A. gracile eggs from one pond in Lincoln County, Coast Range, Oregon, USA, in February 1996. Hyla regilla eggs were collected from one pond in Benton County, Willamette Valley, Oregon, USA, in March 1996. 
Bufo boreas eggs were collected from Lost Lake, Linn County, Cascade Mountains, Oregon, and R. pretiosa eggs were collected from Gold Lake, Lane County, Cascade Mountains, Oregon. For each species, eggs from 10 different clutches were collected in late stages of development in areas where they were abundant. Each clutch or piece of clutch was introduced in separate 4-L containers in the laboratory and eggs were allowed to hatch. Larvae were used in experiments within a week after hatching.

\section{Experimental procedures}

Four species (excluding $R$. aurora) were tested for sensitivity to nitrate solutions, and all five species were tested for sensitivity to nitrite solutions. Each species was tested independently. The experiments were conducted in the laboratory at $15^{\circ} \mathrm{C}$ under artificial incandescent light with a natural photoperiod. Newly hatched tadpoles were exposed to an $\mathrm{N}$-nitrate and $\mathrm{N}$-nitrite dilution series (six treatment levels) and one control (no nitrate or nitrite added) in a 15-d static test [30]. Tests were conducted in 4- $\mathrm{L}$ tanks containing $3 \mathrm{~L}$ of solution. The 21 tanks (three replicates for treatment) for each experiment were randomly assigned to one of seven concentrations of chemical. Potassium nitrate and sodium nitrite were used to make up solutions of nitrate and nitrite, respectively. For nitrate treatments, we used final concentrations of $0,0.78,1.56,3.12,6.25,12.5$, and 25 $\mathrm{mg} \mathrm{N}-\mathrm{NO}_{3}-/ \mathrm{L}$. In nitrite treatments, we used final concentrations of $0,0.22,0.44,0.88,1.75,3.5$, and $7 \mathrm{mg} \mathrm{N}-\mathrm{NO}_{2}-/ \mathrm{L}$. We used the same concentrations for all species based on pilot trials conducted on $R$. pretiosa. We used dechlorinated tap water chemically treated to remove ammonia, chlorine, chloramine, and heavy metals and to buffer $\mathrm{pH}$. At the beginning of the experiment, 20 larvae (two from each clutch $\times 10$ clutches for each species) were randomly assigned to each treatment and were placed in a tank. Larvae were fed ad libitum with lettuce that was previously washed with distilled water and boiled for $1 \mathrm{~min}$. Ion concentrations in the tanks were checked at day 7 and at the end of the experiments. Chemical analyses of water were conducted using standard methodology [31]. Nitrate and nitrite concentrations in the samples were determined colorimetrically on a Lachat Flow-Injection Autoanalyzer (Lachat Instruments, Milwaukee, WI, USA). No significant deviations (greater than 25\%) from the original ion concentrations were detected. Solutions were replaced and tanks were cleaned at day 7. All the experiments were conducted for $15 \mathrm{~d}$. Larval mortality, activity level and behavior, and the presence of abnormalities were monitored, and dead larvae were removed every $24 \mathrm{~h}$.

\section{Analysis of data}

To determine if sensitivity to nitrate or nitrite differed among species, we used analysis of covariance (ANCOVA), with the dependent variable the proportion of dead larvae at 4 and $15 \mathrm{~d}$ (arcsin of square-root transformed), nitrogen concentration as the covariate, and species as the categorical variable. To determine if survivorship differed among species at a specific ion concentration, we used post hoc univariate analysis of variance (ANOVA). Median lethal concentrations (LC50s) were calculated for days 4, 7, and 15 using the probit/ $\log$ method [32].

\section{RESULTS}

\section{Nitrate treatments}

No mortality occurred in control tanks. There were significant differences in sensitivity among species (Table 1). In
Table 1. Results of overall ANCOVAs for species effect of nitrate on larval survival of four amphibian species (Rana pretiosa, Bufo boreas, Hyla regilla, and Ambystoma gracile); dependent variables are mortality at 4 and $15 \mathrm{~d}$ (arcsin of square root transformed) and the covariate is nitrate concentration

\begin{tabular}{llrrrr}
\hline Variable & $\begin{array}{c}\text { Source of } \\
\text { variation }\end{array}$ & $d f$ & $\begin{array}{c}\text { Mean } \\
\text { squares }\end{array}$ & \multicolumn{1}{c}{$F$} & \multicolumn{1}{c}{$p$} \\
\hline $4 \mathrm{~d}$ & Concentration & 1 & 0.128 & 17.26 & $<0.001$ \\
& Species & 3 & 0.030 & 4.08 & 0.009 \\
& Error & 79 & 0.007 & & \\
$15 \mathrm{~d}$ & Concentration & 1 & 1.405 & 44.51 & $<0.001$ \\
& Species & 3 & 0.575 & 18.21 & $<0.001$ \\
& Error & 79 & 0.032 & & \\
\hline
\end{tabular}

higher concentrations of nitrate, larvae of A. gracile and $R$. pretiosa reduced feeding activity; swam less vigorously; showed disequilibrium, abnormalities (mainly edemas and bent tails), and paralysis; and many eventually died. Bufo boreas and $H$. regilla larvae experienced very low effects at all concentrations (Fig. 1). At day 4, A. gracile was the most sensitive species and at the highest concentration showed significant mortality $\left(\mathrm{ANOVA}_{3,8}: F=37.23, p<0.001\right.$ ). The three anurans did not experience significant mortality at day 4 in any nitrate concentration.

At day 15 , there were differences in sensitivity among species (Table 1 ), and $R$. pretiosa and $A$. gracile were the most sensitive (Fig. 1). The LC50 for $R$. pretiosa was 16.45 $( \pm 1.383) \mathrm{mg} \mathrm{N}-\mathrm{NO}_{3}{ }^{-} / \mathrm{L}$ and, for A. gracile, was $23.39 \mathrm{mg} \mathrm{N}-$ $\mathrm{NO}_{3}-/ \mathrm{L}$. At nitrate concentrations of $12.5 \mathrm{mg} \mathrm{N}-\mathrm{NO}_{3}^{-} / \mathrm{L}, R$. pretiosa was more sensitive than A. gracile (Fig. 1; ANOVA $_{3,8}$ : $F=9.389, p<0.01)$. Post hoc comparisons in the ANCOVA and in the significant ANOVA for $25 \mathrm{mg} \mathrm{N}-\mathrm{NO}_{3}{ }^{-} / \mathrm{L}$ did not show significant differences in sensitivity between $R$. pretiosa and $A$. gracile (Table 1).

\section{Nitrite treatments}

No mortality occurred in control tanks. At higher concentrations, larvae of the five species reduced feeding activity; swam less vigorously; showed disequilibrium, abnormalities (mainly edemas and bent tails), and paralysis; and many eventually died. The observed effects increased with both concentration and time, and there were significant differences in sensitivity among species (Table 2). The LC50 values indicate a high sensitivity of the five amphibians to nitrite (Table 3 ). At

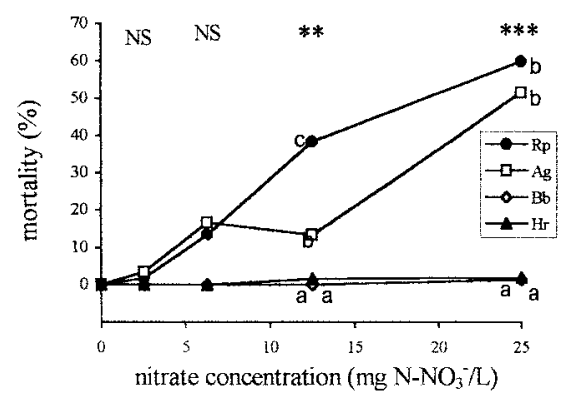

Fig. 1. Sensitivity to nitrate in larvae of four amphibian species after $15 \mathrm{~d}$ of exposure. $\mathrm{Rp}=$ Rana pretiosa, $\mathrm{Bb}=$ Bufo boreas, $\mathrm{Hr}=$ Hyla regilla, $\mathrm{Ag}=$ Ambystoma gracile. Significance levels of univariate ANOVAs for each concentration (NS, $p>0.05$; **, $p<0.01$; ***, $p<0.001)$ and post hoc pairwise comparisons for the significant ANOVAs are addressed (different letter indicates significant differences). 
Table 2. Results of overall ANCOVAs for species effect of nitrite in larval survival of five amphibian species (Rana pretiosa, Rana aurora, Bufo boreas, Hyla regilla, and Ambystoma gracile); dependent variables are mortality at 4 and $15 \mathrm{~d}$ (arcsin of square root transformed) and the covariate is nitrite concentration

\begin{tabular}{llrrrc}
\hline Variable & $\begin{array}{c}\text { Source of } \\
\text { variation }\end{array}$ & $d f$ & $\begin{array}{c}\text { Mean } \\
\text { squares }\end{array}$ & \multicolumn{1}{c}{$F$} & $P$ \\
\hline $4 \mathrm{~d}$ & Concentration & 1 & 6.548 & 227.90 & $<0.001$ \\
& Species & 4 & 0.665 & 23.14 & $<0.001$ \\
& Error & 99 & 0.029 & & \\
$15 \mathrm{~d}$ & Concentration & 1 & 31.285 & 270.49 & $<0.001$ \\
& Species & 4 & 0.467 & 4.04 & 0.0045 \\
& Error & 99 & 0.116 & & \\
\hline
\end{tabular}

day 4 , there were differences in mortality among species (Table 2) and A. gracile had the highest mortality rate (Fig. 2a). Ambystoma gracile larvae experienced a strong acute effect at low nitrite concentrations, and only $B$. boreas showed low mortality at all concentrations at this time (Fig. 2a). At day 7, A. gracile was still the most sensitive species at lower nitrite concentrations, but $R$. pretiosa had more mortality at higher concentrations (Fig. 2b).

At day 15, the five species were very sensitive to nitrite (Fig. 2c). There were differences in mortality among species (Table 2), and $R$. pretiosa was the most sensitive (Fig. 2c; mean mortality $[ \pm \mathrm{SE}]$ of $16.7 \%[ \pm 4.04 \%]$ in $0.44 \mathrm{mg} \mathrm{N}-\mathrm{NO}_{2}^{-}$

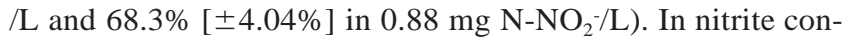
centrations of $0.88 \mathrm{mg} \mathrm{N}-\mathrm{NO}_{2}^{-} / \mathrm{L}, R$. pretiosa was seven times more sensitive than $R$. aurora and 20 times more sensitive than $H$. regilla.

\section{DISCUSSION}

Ambystoma gracile is still present in lowland valleys of western Oregon and Washington, while $R$. pretiosa is extremely rare in these areas [24,25]. Our experiments showed a strong sensitivity of $R$. pretiosa and A. gracile larvae to relatively low levels of both nitrate and nitrite. However, there were some differences between both species in their response to the ions. Ambystoma gracile had a stronger acute effect, but in most of the treatments, some larvae survived until the end of the experiments. Thus, some individuals may be more resistant to nitrate and nitrite than others and they may be able to survive in relatively nitrate-nitrite-enriched areas. However, R. pretiosa did not show quick adverse effects to the ions, but at day 15 , all $R$. pretiosa tadpoles showed a similar high sensitivity and death was relatively synchronous. Our results suggest that nitrogen-based chemical fertilizers are a possible cause of the decline of $R$. pretiosa in the lowlands.

Introduced bullfrogs, Rana catesbeiana, may have contributed to the decline of $R$. pretios $a$ and other amphibians in the Willamette Valley $[6,29,33]$. Bullfrogs may compete with or prey upon native amphibian species and seem to alter their use of habitat [34]. Bullfrogs may also be more tolerant to
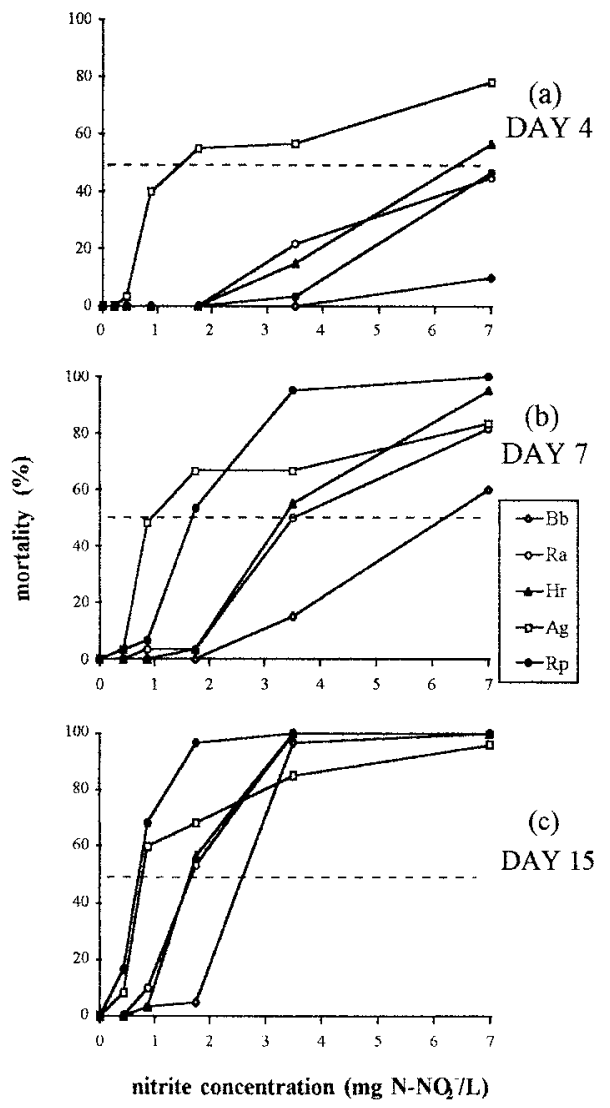

Fig. 2. Sensitivity to nitrite in larvae of five amphibian species after an exposure of (a) 4, (b) 7, and (c) $15 . \mathrm{Rp}=$ Rana pretiosa, $\mathrm{Ra}=$ Rana aurora, $\mathrm{Bb}=$ Bufo boreas, $\mathrm{Hr}=$ Hyla regilla, $\mathrm{Ag}=$ Ambystoma gracile.

nitrogen-based fertilizers than other amphibians, thus allowing their number to increase in areas where there are other amphibians. Huey and Beitinger $[15,16]$ found that bullfrog tadpoles were relatively tolerant to nitrite, showing a reduced methemoglobin response. This apparent difference in sensitivity to nitrite could be contributing to the negative association between bullfrogs and other amphibians in areas with an intense agricultural use.

Many public water supplies in the United States contain levels of nitrate that routinely exceed concentrations of $10 \mathrm{mg}$ $\mathrm{N} / \mathrm{L}$ [8]. In the Willamette Valley, average nitrate concentrations of 17.8 and $21.9 \mathrm{mg} \mathrm{N} / \mathrm{L}$ were recorded in water samples from some crop soils receiving recommended rate of nitrogen fertilization [35]. These average values are highly toxic for $R$. pretiosa and $A$. gracile. Peak nitrate concentrations that eventually would affect amphibians could be several times higher than average values [36]. Excreted nitrogen by grazing cattle can also exceed recommended levels of nitrate in drinking water [37]. Nitrates themselves are of low toxicity, but they create health problems when reduced to nitrites [38]. Levels of nitrite

Table 3. Median lethal concentrations ( $\mathrm{LC} 50 \pm \mathrm{SE}$ ) of nitrite $\left(\mathrm{mg} \mathrm{N}-\mathrm{NO}_{2}^{-} / \mathrm{L}\right)$ for aquatic larvae of five amphibian species at 4, 7 and 15 days of exposure. Standard errors for LC50 are in parentheses

\begin{tabular}{cccccc}
\hline Day & R. pretiosa & R. aurora & B. boreas & H. regilla & A. gracile \\
\hline 4 & $6.82(0.615)$ & $5.59(1.446)$ & $>7.0$ & $5.50(0.742)$ & $1.90(0.737)$ \\
7 & $1.30(0.345)$ & $4.00(1.021)$ & $5.38(0.646)$ & $3.60(0.650)$ & $1.54(0.598)$ \\
15 & $0.57(0.033)$ & $1.19(0.268)$ & $1.75(0.612)$ & $1.23(0.312)$ & $1.01(0.279)$ \\
\hline
\end{tabular}


in natural aquatic habitats are usually low, but under some circumstances and in specific areas such as shore sites with high contents of organic matter, nitrite concentrations can rise to toxic levels higher than $1 \mathrm{mg} \mathrm{N}-\mathrm{NO}_{2}^{-} / \mathrm{L}$ [39]. Nitrate can also be reduced to nitrite in the gastrointestinal tract of animals, which then reaches the bloodstream of animals, particularly the youngest ones [8].

The recommended level of nitrate for drinking water (10 $\mathrm{mg} \mathrm{N}-\mathrm{NO}_{3}{ }^{-} / \mathrm{L}$; [8]) is moderately toxic for $R$. pretiosa. The recommended level of nitrate for warm-water fishes $(90 \mathrm{mg}$ $\mathrm{N}-\mathrm{NO}_{3}-\mathrm{L}$; [8]) is almost four times higher than the LC50 at $15 \mathrm{~d}$ for $R$. pretiosa and two times higher than that for $A$. gracile. The recommended level of nitrite for drinking water (1 mg N-NO ${ }_{2}^{-} / \mathrm{L}$; [8]) is highly toxic for $R$. pretiosa and $A$. gracile and is moderately toxic for the rest of the amphibians tested. The LC50 for nitrite at $15 \mathrm{~d}$ for all the studied species (Table 3) was largely below the recommended level for warmwater fishes $\left(5 \mathrm{mg} \mathrm{N}-\mathrm{NO}_{2}{ }^{-} / \mathrm{L}\right.$; [8]). These results indicate that U.S. Environmental Protection Agency water-quality criteria do not guarantee the survival of some protected and endangered amphibians. We agree with other authors who suggest the need to establish water quality criteria for amphibians [40], and we consider that larvae of sensitive species could be used as bioindicators of water quality in the Pacific Northwest.

Acknowledgement-We thank Douglas Chivers, Joseph Kiesecker, Valentín Pérez-Mellado, Miguel Lizana, Erica Wildy, and Jill DeVito. We also thank Dave Myrold and Lachat Laboratory, U.S. Department of Agriculture, Corvallis, Oregon, for their technical support. Funding was provided by the Ministry of Education and Culture of Spain (grant E95-16796691 to A. Marco and grant E94-16794747 to C. Quilchano), Oregon State University, Department of Zoology Research Funds, and the U.S. National Science Foundation (grant DEB 9423333 to A.R. Blaustein).

\section{REFERENCES}

1. Wake DB. 1991. Declining amphibian populations. Science 253: 422-424.

2. Wilson EO. 1992. The Diversity of Life. Belknap, Cambridge, MA, USA

3. Ehrlich PR, Ehrlich AH, Pimm S. 1996. Betrayal of science and reason. Nature 383:494.

4. Blaustein AR, Wake DB, Sousa WP. 1994. Amphibian declines: Judging stability, persistence, and susceptibility of populations to local and global extinctions. Conserv Biol 8:60-71.

5. Blaustein AR, Wake DB. 1995. The problem of declining amphibian populations. Sci Am 272:52-57.

6. Stebbins RC, Cohen NW. 1995. A Natural History of Amphibians. Princeton University Press, Princeton, NJ, USA.

7. Reaser JK. 1996. The elucidation of amphibian declines: Are amphibian populations disappearing? Amphib Reptile Conserv 1:4-9.

8. U.S. Environmental Protection Agency. 1986. Quality criteria for water. EPA 440/5-86-001. Technical Report. Washington, DC.

9. Organization for Economic Cooperation and Development. 1986. Water Pollution by Fertilizers and Pesticides. Paris, France.

10. Russo RC, Thurston RV. 1977. The acute toxicity of nitrite to fishes. In Tubb RA, ed, Recent Advances in Fish Toxicology. EPA 600/3-77-085. U.S. Environmental Protection Agency, Corvallis, OR.

11. Bogardi I, Kuzelka RD, Ennenga WG. 1991. Nitrate Contamination: Exposure, Consequence, and Control. NATO ASI Series G, Vol 30-Ecological Sciences. Springer-Verlag, New York, NY, USA.

12. Lewis WM Jr, Morris DP. 1986. Toxicity of nitrite to fish: A review. Trans Am Fish Soc 115:183-194.

13. Williams EM, Eddy FB. 1989. Effect of nitrite on the embryonic development of Atlantic salmon (Salmo salari). Can J Fish Aquat Sci 46:1726-1729.

14. Oldham RS, Lathan DM, Hilton-Brown D, Towns M, Cooke AS, Burn A. 1997. The effect of ammonium nitrate fertilizer on frog (Rana temporaria) survival. Agric Ecosys Environ 61:69-74.
15. Huey DW, Beitinger TL. 1980a. Hematological responses of larval Rana catesbeiana to sublethal nitrate exposures. Bull Environ Contam Toxicol 25:574-577.

16. Huey DW, Beitinger TL. 1980b. Toxicity of nitrite to larvae of the salamander Ambystoma texanum. Bull Environ Contam Toxicol 25:909-912.

17. Dappen GE. 1982. Effects of nitrates upon hemopoietic, lymphoid and vascular tissues of tadpoles and frogs. Proc Nebr Acad Sci Affiliated Socs 92:23.

18. Oldham RS, Hilton-Brown D. 1992. Effect of agricultural fertilizers on amphibians (C): NPK granules tested separately. Contract Report F72-15-05. Nature Conservancy Council, London, UK.

19. Watt PJ, Oldham RS. 1995. The effect of ammonium nitrate on the feeding and development of larvae of the smooth newt, Triturus vulgaris (L.), and on the behaviour of its food source, Daphnia. Freshwater Biol 33:319-324.

20. Cooke AS. 1981. Tadpoles as indicators of harmful levels of pollution in the field. Environ Pollut Ser A Ecol Biol 25:123-133.

21. Baker J, Waights V. 1993. The effect of sodium nitrate on the growth and survival of toad tadpoles (Bufo bufo) in the laboratory. Herpetol J 3:147-148.

22. Berger L. 1989. Disappearance of amphibian larvae in the agricultural landscape. Ecol Int Bull 17:65-73.

23. Hecnar SJ. 1995. Acute and chronic toxicity of ammonium nitrate fertilizer to amphibians from southern Ontario. Environ Toxicol Chem 14:2131-2137.

24. McAllister KR, Leonard WP. 1997. Washington State status report for the Oregon spotted frog. Washington Department of Fish and Wildlife, Olympia, WA, USA.

25. Hayes MP, Engler JD, Haycock RD, Knopp DH, Leonard WP, McAllister KR, Todd LL. 1997. Status of the Oregon spotted frog (Rana pretiosa) across its geographic range. Proceedings, Workshop on Spotted Frogs of Oregon, Oregon Chapter of the Wildlife Society, Corvallis, OR, USA, August 15.

26. Marshall DL. 1989. Status of the spotted frog in Oregon. Final Report, Oregon Department of Fish and Wildlife, Portland, OR, USA.

27. Hayes MP. 1994. Current status of the spotted frog (Rana pretiosa) in western Oregon. Report 94-1-01:1-11. Oregon Department of Fish and Wildlife, Portland, OR, USA.

28. Blaustein AR, Wake DB. 1990. Declining amphibian populations. A global phenomenon? Trends Ecol Evol 5:203-204.

29. Nussbaum RA, Brodie ED Jr, Storm RM. 1983. Amphibians and Reptiles of the Pacific Northwest. University of Idaho Press, Moscow, ID, USA.

30. Stephen CE. 1975. Methods for acute toxicity tests with fish, macroinvertebrates and amphibians. EPA-660/3-75-009. U.S. Environmental Protection Agency, Corvallis, OR.

31. American Public Health Association. 1980. Standard Methods for the Examination of Water and Wastewater, 15th ed. Washington, DC.

32. Gad S, Weil CS. 1986. Statistics and Experimental Design for Toxicologists. Telford Press, Caldwell, NJ, USA.

33. Hayes MP, Jennings MR. 1986. Decline of ranid frog species in western North America: Are bullfrogs (Rana catesbeiana) responsible? J Herpetol 20:490-509.

34. Kiesecker JM, Blaustein AR. 1997. Population differences in responses of red-legged frogs (Rana aurora) to introduced bullfrogs. Ecology 78:1752-1760.

35. Brandi-Dohrn FM, Dick RP, Hess M, Kauffman SM, Hemphill DD Jr, Selker JS. 1997. Nitrate leaching under a cereal rye cover crop. J Environ Qual 26:181-188.

36. Scholefield D, Lord EI, Rodda HJE, Webb B. 1996. Estimating peak nitrate concentrations from annual nitrate loads. J Hydrol $186: 355-373$.

37. Hack-Ten-Broeke MJD, De-Groot WJM, Dijkstra JP. 1996. Impact of excreted nitrogen by grazing cattle on nitrate leaching. Soil Use Manage 12:190-198.

38. Eddy FB, Williams EM. 1994. Freshwater fish and nitrite. In Howells G, ed, Water Quality for Freshwater Fish. Gordon and Breach Science, Yverdon, Switzerland, pp 117-143.

39. McCoy EF. 1972. Role of bacteria in the nitrogen cycle in lakes. EHR 16010. U.S. Environmental Protection Agency, Water Pollution Control Service, Washington, DC.

40. Boyer R, Grue CE. 1995. The need for water quality criteria for frogs. Environ Health Perspect 103:352-357. 